УДК $32+316$

https://doi.org/10.34142/24130060.2019.19.2.10

\title{
ТЕОРІЇ СКЛАДНОСТІ ТА ЇХ ЗАСТОСУВАННЯ В СОЦІАЛЬНИХ НАУКАХ
}

\author{
В.Л. Пасісниченко, І.М. Пасісниченко
}

Харківський національний педагогічний університет імені Г.С. Сковороди

У статті аналізуються теорії складності (complexity theories) з точки зору доиільності їх використання в дослідженнях сочіальних теоретиків. Відкриття можливості вивчення складних систем, яким притаманні властивості самоорганізації як аутопойезису, нелійності та стану нерівноваги, спонукало соиіальних теоретиків до використання інструментарію науки про складність у дослідженнях сочіальної складності в межах політології, сочіології, міжнародних відносинах та інших дисциплінах про суспільство та людину.

В якості конкретного прикладу розглядається відповідний внесок у соиіальну теорію сочіолога Дюсона Уррі. Всупереч емпіричній та позитивістській традиції він запропонував пост-дисииплінарний підхід на підставі того, щзо як соціальні, так $i$ природничі науки характеризуються належністю до складних систем. Наш аналіз еволюиї його поглядів фіксує в якості ї̈ початкового і фундаментального етапу саме теорію складності. Ї̈ можна назвати головним поворотом, який Дж. Уррі здійснив у сочүіальній теорії. Всі інші його інновації, зокрема теорія соціальної мобільності та геоекологічний підхід у питаннях природи, планетарного спожсивання $і$ людського тіла, стали закономірним наслідком изього фокусу на теорї складності.

Ключові слова: сочіальні та природничі науки, теорї складності, теорії хаосу, мобільність. Джон Уррі.

\section{ТЕОРИИ СЛОЖНОСТИ И ИХ ИСПОЛЬЗОВАНИЕ В СОЦИАЛЬНЫХ НАУКАХ}

\section{В.Л. Пасисниченко, И.Н. Пасисниченко}

В статье анализируются теории сложности (complexity theories) с точки зрения обоснованности их использования в исследованиях сочиальных теоретиков. Открытие возможности изучения сложных систем, которые обладают свойствами самоорганизации как аутопоэзиса, нелинейности и неравновесности подтолкнуло сочиальных теоретиков к использованию этого инструментария в изучении социальных сложных систем в рамках политологии, сочиологии, международных отночений и других дисииплин об обществе и человеке.

В качестве конкретного примера рассматривается соответствующий вклад в сочиальную теорию сочиолога Дж. Урри. В противовес эмпирической и позитивистской традиции он отстаивает пост-дисциплинарньй подход, исходя из того, что и сочииальные, и естественные науки характеризуются принадлежностью к сложным системам. Наш анализ эволюции его взглядов фиксирует в качестве ее стартового и фундаментального этапа именно теорию сложностей. Ее можно назвать главным поворотом, который Дж. Урри совершил в сочиальной теории. Все другие его инновации, в частности теория сочииальной мобильности и гео-экологический подход подход в 
вопросах природы, планетарного потребления и человеческого тела, стали лишь закономерным следствием этой сфокусированности на теории сложных систем

Ключевые слова: социальные и естественные науки, теория сложных систем, теория хаоса, мобильность, Джон Урри.

\section{COMPLEXITY THEORIES AND THEIR APPLICATIONS FOR SOCIAL SCIENCES}

\section{Pasisnychenko, I. Pasisnychenko}

This article examines complexity theories and their applicability for social studies. Once these theories revealed complex system of autopoietic self-organization, nonlinearity and far from equilibrium social theoretics were encouraged to apply complexity methodology to investigate social complexity in a frame of political studies, sociology, international relations and other social disciplines

As a particular case, the article studies John Urry's profound contributions to complexity theoretical shifts in social science. He was not only one of the most important British sociologists, but also a scholar network builder and public intellectual who changed the face of British, and indeed global, social theory. Known as a creator of the new mobility paradigm associated with a 'Lancaster School', he stands in contrast to the empiricist traditions in American and British social sciences, while struggling for post-disciplinary approach against the hierarchies of academic departments, and their disciplinary closure. This also explains his critique of conventional sociology and its division from the natural sciences.

J. Urry was primarily a macro-level thinker concerned with systems and global processes. Therefore, his project starts with complexity theory and its implications in terms of global complexity, complexity of social sciences in opposition to its previous linearity and structurelagent duality. J. Urry argues for breaking down the division between 'natural' and 'social' sciences, since both are characterized by complexity This complexity turn led Urry directly into his conceptualization of mobilities as a second theoretical turn, which deals with dynamic urban forms and automobility. Finally, a third theoretical turn in his thinking is geoecological. Here J. Urry is acting as a micro-level theorist of the body, leisure, consuming, tourism and nature. Tracing this trajectory of his theoretical evolution is more informative for it moves us from his early recognition of large-scaled complexity into reconsidered human-scaled problems of how we ought to live in the world.

Key words: social and natural sciences, theory of complex systems, chaos theory, mobility, John Urry.

\section{Постановка проблеми. Революційні зрушення у сучасному} природознавстві, насамперед у квантовій механіці, що зруйнували механістичну об'єктивістську ньютонівську наукову парадигму, спровокували активний пошук нових наукових орієнтирів. Повернення в науку ролі людського фактору, темпоральності, випадковості разом 3 усвідомленням нелінійності процесів розвитку знайшло своє відображення у появі так званих complexity theories. В англійській мові для їх характеристики використовується поняття «complexity», яке в українській мові не зовсім точно відображається у терміні «складність». Часто також вживається і 
поняття «комплексність». Зрозуміло, що цей напрямок розвитку теорій складності є надзвичайно популярним серед сучасних природознавців. Разом iз тим важливим є питання можливості застосування цих теорій у галузі соціальних наук. 3 одного боку, суспільство та його підсистеми також мають очевидні ознаки складності. 3 іншого боку, ми маємо бути свідомими загрози редукціонізму, коли методологія природничих наук може спрощено переноситися на сферу соціальних наук. Тому на особливу увагу заслуговують вже наявні приклади застосування теорій складності окремими соціальними теоретиками і стосовно певного кола проблематики.

Аналіз актуальних досліджень. Попри популярність теорій складності серед представників природних наук в їх середовищі також продовжуються дискусії щодо визначення самого поняття. Деякі дослідники навіть пропонують для аналізу нелінійних процесів використовувати іншу дефініцію - теорії хаосу (Ruelle, 1993; Hall, 1991). Для нашого дослідження особливо цінними є роботи, присвячені можливостям використання даного методологічного інструментарію в галузі соціальної теоріï (Kiel and Elliot, 1996; Eve, Horsfall and Lee, 1997). Далі ми розглянемо, до якої соціальної проблематики в першу чергу застосовується нова методологія. Як конкретний кейс буде проаналізовано внесок у розробку теорій складності щодо соціальної сфери Дж. Уррі.

Мета статті полягає в аналізі теорій складності 3 точки зору можливості їх використання в дослідженнях соціальних теоретиків i, зокрема, їх місця у творчому спадку соціолога Джона Уррі.

Виклад основного матеріалу. Природа складних систем є об'єктом жвавих наукових дискусій. Вочевидь вона пов'язана 3 феноменами, які характеризуються як нелійні, неврівноважені та такі, що саморганізовуються i самонаправляються. Кращому розумінню природи складності допомагає виділення двох іiі різновидів (Katz, 1986, p. 1-2). Перший тип алгометричної складності спирається на математичні та комп'ютерні інструменти i фактично зводиться до можливостей прорахування та моделювання складних 
систем. Другий тип організаціийної складності пов’язаний 3 так званою дивною поведінкою системи (Nicolis and Prigogine, 1989, p. 8), і саме він виглядає більшою мірою придатним для екстраполяції в соціальну сферу. У ній ми маємо справу з соціальною складністю в першу чергу як взаємодією соціальних агентів. При цьому вважається, що поведінка кожного агента регулюється невеликим набором простих правил, які часто залежать від локальної інформації та зворотнього зв'язку з минулою поведінкою агента та поведінкою інших агентів. Характеристика та розуміння поведінки кожного 3 агентів не призводить безпосередньо до передбачення чи розуміння поведінки всієї системи. Локальні правила створюють умови для формування закономірностей - стабільна рівновага, іiі різні цикли, нестабільна рівновага, довгий транзит до нової рівноваги, що містить в собі і випадковість. Нарешті, взаємодія агентів є взаємозалежною і впливає на інших у системі, тому видалення агента має наслідки для всієї системи.

Зважаючи на те, що різноманітні соціальні системи характеризуються як складні, в соціальних дисциплінах зростає використання теорій складності і відповідного складного моделювання систем. У рамках політології вони застосовуються для вивчення міжнародної дипломатії та війни, електоральної конкуренції і систем голосування, злочинної поведінки й покарань та політичних мереж (Axelrod, 1997; De Marchi, 2005; Laver, 2005; Page, 2010).

Наприклад, дослідники, що вивчають дипломатію та війну, розробили рамки моделювання для аналізу чутливості міжнародних альянсів до змін у нерівному розподілі ресурсів між партнерами альянсу. Коли країна, що розвивається, знаходить нафту, досліджується, який вплив це має на військові чи торгові альянси. Складні моделі систем можуть дати можливість проаналізувати наслідки таких змін на рівні системи, які часто є нелінійними.

Вчені також використовували теорії складності, аби виявити умови, за яких група різних людей із різними способами вирішення проблеми може вибрати більш ефективну публічну політику, ніж група однорідних осіб, які 
так само мають ту саму проблему. Різноманітність, за їх висновками, може в загальних обставинах покращити колективне ухвалення рішень у законодавчих органах та різних організаціях. Тому аналіз соціальних та політичних мереж так само все більше залучає моделювання складних систем. Існують моделі, які допомагають дослідникам краще розуміти умови, за яких соціальні мережі заохочують інновації та їх поширення серед своїх агентів.

Моделювання складних систем іноді сприймається як виклик традиційним ігровим методам моделювання. Але більшість користувачів теорій складності, які моделюють у політичній науці, розглядають їх як доповнення до ігрових методів. Досить багато складних системних моделей у політичній науці базуються на принципах теорії ігор, i самі дослідники зазвичай публікують роботи, що охоплюють різні інструменти моделювання, включаючи теорію ігор.

Разом із тим треба наголосити на важливій відмінності теорій складності. Вона полягає в тому, що в основі теорія ігор, згідно Дж. фон Нейману та Дж. Нешу, лежить припущення, що агенти $є$ раціональні (займаються оптимізацією) та розумні (вони знають, в яку гру вони грають). Моделі систем складності можуть порушувати обидва ці припущення, особливо останнє. Тому значна частина досліджень складності у політичній науці зосереджує увагу на моделях, де агенти не є повністю раціональними і тому зображуються як адаптивні та обмежено раціональні (Miller, Page, 2007). Загалом це означає, що агенти відображають наступні характеристики: вони не повністю оптимізують свої корисні функції з огляду на доступну їм інформацію; вони не дивляться наперед, аби мати можливість точно передбачити ймовірність результатів своєї поведінку у майбутньому; і вони короткозорі у тому, що не мають інформації за межами своєї локальної зони взаємодії.

Отже використання теорій складності щодо соціальних наук найкраще описується як набір інструментів для аналізу. Вони дозволяють краще 
зрозуміти мікрорівень мотивації та взаємодії між агентами, приймаючи до уваги їх інтеракцію, зворотні зв'язки та нелінійні ефекти. Наприклад, можна виявити причини переходу динаміки макрорівня від однієї фази (наприклад, багатополярності в міжнародній системі) до іншої (наприклад, однополярності). У цьому сенсі дослідники складних систем створюють щось аналогічне експериментальним лабораторіям, а складні моделі стають платформами для детального аналізу різноманітних питань, особливо про те, як взаємодії на мікрорівні формують шаблони на макрорівні.

Яскравим прикладом своєрідної лабораторії 3 дослідження різноманітних проблем, але з акцентом на теоріях складності, можна назвати творчу спадщину британського соціолога Джона Урpi (1946-2016). Його науковий доробок у цій проблематиці викликав значні парадигмальні зрушення у соціальній теорії в цілому. Зазвичай його ім'я пов'язують із введенням теорії мобільності, що концептуалізує простір i час поза територіально фіксованими спільнотами. Цікаво, що вчений, який фактично здійснив поворот до мобільності у сучасній соціальній теорії, залишався протягом усього свого професійного життя корінням в одному місці, в університеті Ланкастера. Але при цьому він умів підтримувати зв’язки 3 колегами по всьому світові, створювати середовище для спільної роботи. Тому більша частина його робіт народилась у співавторстві. Цьому сприяли такі його особисті якості як скромність і несприйняття ієрархічності у стосунках. Це також витікало 3 його чіткої неоліберальної та антиелітистської позиції.

Дж. Уррі розглядав свої роботи як опозиційні і до американської соціології, і до британського емпіризму. Такий антипозитивістський підхід допомагає пояснити триваюче небажання Американської соціологічної асоціації та деяких соціологів в інших країнах долучитися повною мірою до нової парадигми мобільності. Більш того, суперечливість в оцінці спадщини Дж. Уррі як соціолога і соціального теоретика одночасно пов'язані з його прагненням розвивати пост-дисциплінарну соціальну теорію. Для нього це 
була відповідь на напади уряду М. Тетчер на університети і особливо на скорочення університетських програм із суспільних наук. У своєму прагненні до стирання міждисциплінарних кордонів він доходить до ідеї єдності соціальних та природничих наук на підставі того, що вони мають справи зі складними системами. Тому Дж. Уррі слід розглядати не тільки як теоретика мобільності, але й звернути увагу на його недооцінене теоретизування складностей, у тому числі з точки зору соціальних наук. Отже він теж обирає незвичний шлях, як і його німецький колега Ніклас Луман. Останній також синтезує соціологію 3 новітніми ідеями природознавців, продукує свою соціологію аутопоезиса та часто отримує несприйняття від соціологічної спільноти.

У своєму аналізі ми акцентуємо увагу саме на теорії складності Дж. Уррі з вагомих причин. Мова йде не тільки про відображення настанов саме раннього періоду його творчої біографії. Важливо, що саме ці розробки є головними концептуальними інноваціями, на яких вже потім в якості прикладів аналізуються мобільності, зміни клімату, туризм, соціологія тіла.

Раннє дослідження Дж. Уррі щодо проблеми соціального порядку виникло з дебатів в рамках пост-марксистської соціальної теорії британських лівих. Зокрема, він ставить під питання версію теорії структурації Е. Гідденса через іiі нехтування, по-перше, нелінійної складності, за якою структури можуть або не можуть породжувати та відтворювати певні соціальні системи, i, по-друге, обмеження щодо форм соціальної боротьби та ненавмисних наслідків такої боротьби. Саме ця критика дуалізму структури та агента призводить безпосередньо до подальшої роботи Дж. Уррі над проблематикою складностей. Він указує на «глибокі обмеження такого лінійного погляду на глобальний світ» $\mathrm{i}$ описує глобалізацію як «невпорядковану, повну парадоксів, невизначеності й незворотної та суперечливої складності» (2003, p. 58). На його думку, соціальне володіє химерною властивістю взагалі не створюватись агентом чи структурою, а швидше бути циркулюючою сутністю. 
Цей опис невпорядкованого світу також присутній у спільній роботі 3 С. Лешем «Економіки знаків i простору», в якій розглядаються форми дезорганізованого капіталізму кінця XX століття, де об'єкти та суб'єкти є надзвичайно мобільними, i ці мобільності самі структурують i $\epsilon$ структурованими» (Lash and Urry, 1994, p. 3). Тут ми бачимо початки концептуалізації мобільності як ключового поняття, пов'язаного з потоками товарів, капіталу, мігрантів, туристів, робочої сили та інформації. Спираючись на марксистський аналіз обігу товарів та відчуження робочої сили, Дж. Уррі зосереджується на питаннях зростаючої мобільності, швидкості та рефлексивності дезорганізованого капіталізму і складних моделях соціального життя, які ця турбулентність продукує. Тому переосмислення К. Маркса у Дж. Уррі пов'язане безпосередньо 3 його теорією мобільностей, які не є ні макро, ні мікро, але циркулюють між ними через «швидкість, хвилі, безперервний потік, пульсуючу плинність і в’язкість, ритм, гармонію, розбіжність і турбулентність» (Urry, 2007, p. 115). Інша робота Дж. Уррі «Соціологія за межами спільнот» (Urry, 2000a), допомагає закріпити увагу на мобільності як ключовому понятті у новому підході до соціологічної та соціальної теорії.

Таким чином, ми бачимо, як концептуалізація мобільностей відбувається паралельно та виникає з критики теорії структурації. Треба знов наголосити, що вона спирається на теорію складності, адже така мобільність фактично є запереченням лінійності класичної соціологічної традиції 3 вбудованими в неї положеннями про агента та причинність. Навпаки акцентуються процеси, що вважаються більш мобільними, нестабільними, хаотичними, iз непередбачуваними наслідками. Це був новий різновид соціальної теорії в умовах турбулентності кінця ХХ століття, коли люди відчули колапс структур, що мали сенс у минулому. I ця теорія найперше апелює до нового покоління соціальних теоретиків, які шукають нові пояснювальні схеми. 
Надалі, спираючись на свою книгу «Глобальна складність», Дж. Уррі інкорпорує теорію складності в соціологію та в соціальні науки. Він закликає до подолання розмежування між «природними» та «соціальними» науками, оскільки і ті, й інші, за його оцінкою, характеризуються складністю (Urry, 2000а). Водночас він повертається до проблематики раннього періоду щодо дуалізму структури та агента, наводячи аргументи, що людські дії $\epsilon$ обмеженими і що соціальне $є$ істотно неоднорідним: тіло, тексти, машини, архітектура - все це та багато іншого причетні до соціального та репрезентують його. Тому роботи Дж. Уррі в напрямку розвитку теорії складностей були спробою відповісти на початкове головне питання: що створює, відтворює чи руйнує суспільний лад і як ми можемо зрозуміти закономірність народження соціальних змін.

Навіть його теорія мобільності $є$ викликом старій візії простору як контейнера для соціальних процесів, що вносить ідею динамічного, постійного продукування простору в соціальну теорію. Це означає і відхід від дисциплінарного поділу, що відкриває для соціальних теоретиків можливість рухатися в нових напрямах і у складі нових дослідницьких команд. Зокрема, у статті «Мобільна трансформація «публічного» та «приватного» життя» демонструється вплив мобільності на такі сфери суспільства як економіка, громадянське суспільство і держава (Sheller and Urry, 2003). Надалі Дж. Уррі розвиває концепцію мобільності завдяки спільній роботі з колегами у питаннях автомобільності (Sheller and Urry, 2000), (Urry 2004), (Dennis and Urry, 2008), аеромобільності (Urry et al., 2016) і мобільного життя та мережевого капіталу (Elliott and Urry, 2010). Зокрема, спираючись на попередній аналіз формування міста системою автомобілів, Дж. Уррі в роботі «Система «автомобільності»» (Urry, 2004) пробує використати цей емпіричний кейс як зразок того, як виникає така складна система автомобільності, аби мати уяву, як із нею впоратись.

Прагнення розв'язати ці проблеми слід розглядати в ширшому контексті його зростаючого занепокоєння зміною клімату та споживанням 
енергії як ключовими загрозами XXI століття. Як теоретику складних систем, йому зрозуміло, що кліматичні та ресурсні проблеми неможливо вирішити традиційними економічними та біхевіеристськими методами. Тому у відповідній роботі про зміни клімату вони розглядаються як складний системний, соціальний і природний процес (Urry, 2011).

Зрештою, заглиблення у проблематику мобільності призвело до того, що можна назвати вже гео-екологічним поворотом у його мисленні та творчості. Цей ресурсний підхід знайшов відображення в роботах Дж. Уррі як по зміні клімату (Urry, 2011), так і по консьюмерізму (Urry, 1981), офшорам (Urry, 2014), енергетиці та споживанню нафти (Urry, 2013). 3 іншого боку, його продовженням став перехід вченого до аналізу соціології тіла, включно з темою туризму як одного з проявів дозвілля (Macnaghten and Urry, 2000). Однак важливо наголосити, що навіть на цьому людському рівні чітко простежується вплив початкових настанов теорій складності, коли соціальні практики визначаються як дискурсивно сконструйовані, втілені, розміщені у просторі, фіксовані у часі та пов’язані з ризиком (Macnaghten and Urry, 1998).

Висновки і перспективи подальших досліджень. У підсумку наш аналіз теорій складності 3 точки зору можливості їх використання в дослідженнях соціальних теоретиків дозволяє констатувати наступні положення. Розвиток наук про складні системи у формі теорій складності або теорій хаосу розпочався у межах сучасного природознавства як відхід від класичної наукової парадигми 3 іï ньютонівським механіцизмом, позитивістським об'єктивізмом та детермінізмом лінійного розвитку. Він відкрив можливість вивчення складних феноменів, яким притаманні властивості самоорганізації як аутопоезісу, нелійності та неврівноваженості. Водночас нова методологія стала викликом для соціальних теоретиків 3 точки зору розуміння того, що являє собою соціальна складність і наскільки можливо, запобігаючи пастки редукціонізму, плідно використати теорії складності для іiі аналізу. 
Зусилля соціальних теоретиків просунутись у цьому напрямі, як показав наш аналіз, засвідчили досить активне залучення інструментарію науки про складність у політології, соціології, міжнародних відносинах та інших дисциплінах про суспільство та людину. Дослідники складних соціальних систем у такий спосіб створюють своєрідні експериментальні лабораторії. Вони дозволяють краще зрозуміти, як формуються складні паттерни макрорівнів завдяки мікрорівневій взаємодії між агентами, які вже розглядаються як обмежені у своїй раціональній та прогностичній поведінці.

На конкретному прикладі аналізу робіт Дж. Уррі було виявлено, що початковим i фундаментальним етапом його творчості була саме теорія складних систем. Вона стала головним поворотом, який він здійснив не просто в соціології, а в соціальній теорії в цілому. Із ним пов’язані його заклики до пост-дисциплінарності, поєднання соціальних та природничих наук та визнання складності соціальних процесів всупереч лінійності попередньої теорії з іï дуалізмом агента та структури. Всі інші інновації Дж. Уррі, зокрема теорія соціальної мобільності та гео-екологічний підхід у питаннях природи, планетарного споживання i людського тіла, стали закономірним наслідком його фокусу на теорії складності.

\section{ЛІТЕРАТУРА}

1. Axelrod, R. 1997. The complexity of cooperation. Princeton, NJ: Princeton University Press

2. De Marchi, S. 2005. Computational and mathematical modeling in the social sciences. New York: Cambridge University Press

3. Dennis, K. and Urry, J. 2008. After the Car. Cambridge: Polity.

4. Elliott, A and Urry, J. 2010. Mobile Lives. London: Routledge.

5. Eve, R., Horsfall, S. and Lee, M. 1997. Chaos, complexity and sociology. Thousand Oaks:Sage.

6. Hall, N. 1991. The new scientist guide to chaos. London: Pinguine.

7. Katz. 1986. Templets and the explanation of complex patterns. Cambridge: Cambridge University Press.

8. Kiel, L. and Elliot, E. 1996. Chaos theory in the social sciences. Foundations and applications. Ann Arbor: University of Michigan Press.

9. Lash, S. and Urry J. 1994. Economies of Signs and Space. London: Sage.

10. Laver, M., 2005 Policy and the dynamics of political competition. American Political Science Review, 99, p. 263-281. 
11. Macnaghten, P and Urry, J. 1998. Contested Natures. London: Sage.

12. Macnaghten, P. and Urry, J., 2000. Bodies of Nature. Body \& Society, 5 (1), p. 467-481.

13. Miller, J. and Page, S. 2007. Complex adaptive systems. Princeton, NJ: Princeton University Press.

14. Nicolis, G. and Prigogine I. 1989. Exploring complexity. An Introduction. New York: WH Freeman and Co.

15. Page, S. 2010. Diversity and complexity. Princeton, NJ: Princeton University Press.

16. Ruelle, D. 1993. Chance and chaos. London: Pinguine.

17. Sheller, M. and Urry, J. 2000., The city and the car. The International Journal of Urban and Regional Research, 24, p. 737-757.

18. Sheller, M. and Urry, J., 2003. Mobile transformations of 'public' and 'private'life. Theory, Culture \& Society, 20(3), p.107-125.

19. Urry, J. 1981. The Anatomy of Capitalist Societies: The Economy, Civil Society and the State. London: Macmillan.

20. Urry, J. 1990. The Tourist Gaze. London: Sage.

21. Urry, J. 2000a. Sociology Beyond Societies. London: Routledge.

22. Urry, J. 2003. Global Complexity. Cambridge: Polity.

23. Urry, J. 2007. Mobilities. Cambridge: Polity.

24. Urry, J. 2011. Climate Change and Society. Cambridge: Polity.

25. Urry, J. 2014. Offshoring. Cambridge: Polity.

26. Urry, J., 2000b. Mobile sociology. The British Journal of Sociology, 51, p.185-203.

27. Urry, J., 2004. The system of automobility. Theory, Culture\&Society, 21(4/5), p. 25-39.

28. Urry, J, Elliott, A., Radford, D. and Pitt, N., 2016. Globalisation's utopia? On airport atmospherics. Emotion, Space and Society, 19, p. 13-20.

\section{Інформація про авторів}

Пасісниченко Віктор Леонідович - кандидат філософських наук, доцент кафедри політології, соціології і культурології Харківського національного педагогічного університету імені Г.С. Сковороди; e-mail: viktorpasisn@gmail.com; ORCID: http://orcid.org/0000-0002-6849-8672.

Пасісниченко Ірина Миколаївна - кандидат філософських наук, доцент кафедри політології, соціології і культурології Харківського національного педагогічного університету імені Г.С. Сковороди; e-mail: irinapasis@gmail.com; ORCID: http://orcid.org/0000-0002-8899-848X.

Стаття надійшла до редакції: 01.11.2019 р. $\quad$ Прийнята до друку: 25.11.2019 p. 